\title{
KONSEP, TEORI, DAN PRAKTIK OBLIGASI SYARIAH
}

\author{
Muhammad Fadlillah F *
}

\begin{abstract}
Concept, Theory, and Practice of Sharia Bond. One of the growing sharia finance instruments is sharia bond, sharia bonds are securities or certificate that contains the contract between funders (investors) with a given fund (the issuer), sharia bond is supported by the Sharia Securities Act (SBSN) on 9 April 2008, so it can grow a new optimism for national Islamic banking and finance industry. SBSN Act paved the way for the issuance of shria goverment and private bonds, in practice of Islamic bonds may use multiple inclusion models in the form of mudhârabah, ijârah, and musyârakah.
\end{abstract}

Keywords: sharia bond, mudhârabah, ijârah, musyârakah

Abstrak: Konsep, Teori, dan Praktik Obligasi Syariah. Salah satu instrumen pembiayaan syariah yang sedang berkembang adalah obligasi syariah, yaitu surat berharga atau sertifikat yang berisi kontrak antara pemberi dana (pemodal) dengan yang diberi dana (emiten), perkembangan ini didukung oleh adanya UU Surat Berharga Syariah Negara (SBSN) pada 9 April 2008, sehingga dapat menumbuhkan optimisme baru bagi industri perbankan dan keuangan syariah nasional. UU SBSN membuka jalan bagi terbitnya obligasi syariah pemerintah dan swasta, dalam praktiknya obligasi syariah dapat menggunakan beberapa model penyertaan dalam bentuk mudhârabah, ijârah, dan musyârakah.

Kata Kunci: obligasi syariah, mudhârabah, ijârah, musyârakah

Naskah diterima: 18 Januari 2013, direvisi: 19 Maret 2013, disetujui: 28 Maret 2013.

"Fakultas Ekonomi, Universitas Negeri Tula, Federasi Rusia. E-mail: lintasdata@yahoo.co.id 


\section{Pendahuluan}

Salah satu instrumen syariah yang diperkirakan akan berkembang pesat adalah obligasi syariah surah berharga atau sertifikat yang berisi kontrak antara pemberi dana (dalam hal ini pemodal) dengan yang diberi dana (emiten). Jadi surah obligasi adalah selembar kertas yang menyatakan bahwa pemilik kertas tersebut telah mengikut sertakan modalnya kepada perusahaan yang menerbitkan obligasi sebagai bentuk penyertaan dana. Penerbit membayar bagi hasil atas obligasi tersebut pada tanggal-tanggal yang telah ditentukan secara periodik, dan pada akhirnya memberikan nilai modal tersebut pada saat jatuh tempo dengan mengembalikan jumlah pokok dana yang disertakan sebagai modal perusahaan ditambah bagi hasil dari pengguna dana.

\section{Obligasi Mudhârabah}

Mudhârabah atau qirâdh (muqâradah) adalah dua kata yang mempunyai makna yang sama. Penduduk Irak menyebutnya dengan mudhârabah yang banyak dipakai oleh ulama Hanafiyah dan Hanabilah dan penduduk Hijaz menyebutnya dengan qirâdh atau muqâradah yang banyak dipakai ulama Syâfi' 'iyah.

Secara etimologis, mudhârabah (مضاربة) adalah bentuk mashdar dari daraba yudaribu mudhârabah (ضLارب يضارب مضاربة) berasal dari kata darb fi al-ard dengan makna safara (ضرب في (ضی الارض) yang berarti pergi, bermigrasi dalam arti bepergian dalam urusan dagang. ${ }^{1}$ Karena memang orang yang berdagang untuk mencari keuntungan berpergian. Dengan menambahkan alif antara fa fi'il dan 'ayn fi'il maka jadilah dharaba (ضارب) untuk tsulatsi mazîd satu huruf bab mufâ‘alah. Sebagaimana firman Allah dalam surah al-Muzzammil [73] ayat 20:

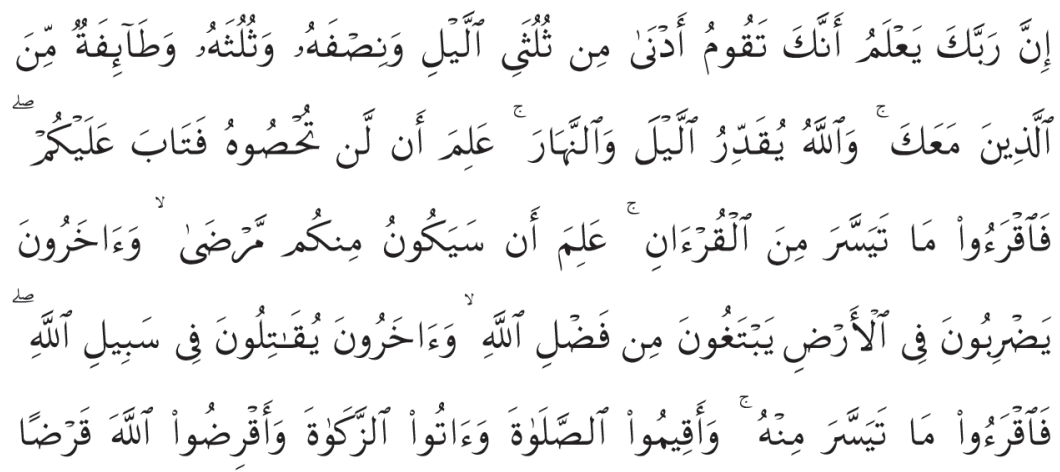

${ }^{1}$ Muhammad 'Imârah, Qâmûs al-Musthalahât al-Iqtishâdiyyah fỉ al-Hadârah al-Islâmiyyah, (Bayrût: Dâr al-Masyrûq, 1993), h. 541. 


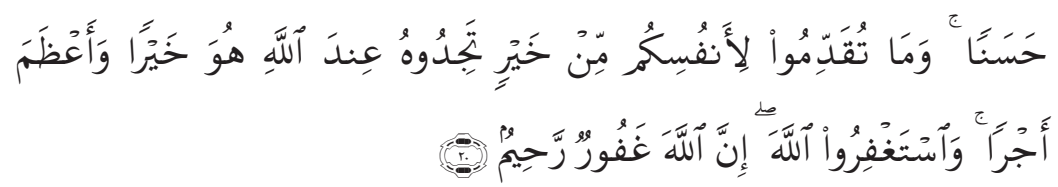

Sesungguhnya Tuhanmu mengetahui bahwasanya kamu berdiri (sembahyang) kurang dari dua pertiga malam, atau seperdua malam atau sepertiganya dan (demikian pula) segolongan dari orang-orang yang bersama kamu. Dan Allah menetapkan ukuran malam dan siang. Allah mengetahui bahwa kamu sekali-kali tidak dapat menentukan batas-batas waktu-waktu itu, maka Dia memberi keringanan kepadamu, karena itu bacalah apa yang mudah (bagimu) dari Alquran. Dia mengetahui bahwa akan ada di antara kamu orang-orang yang sakit dan orang-orang yang berjalan di muka bumi mencari sebagian karunia Allah. Dan orang-orang yang lain lagi berperang di jalan Allah, maka bacalah apa yang mudah (bagimu) dari Alquran dan dirikanlah sembahyang, tunaikanlah zakat, dan berikanlah pinjaman kepada Allah pinjaman yang baik. Dan kebaikan apa saja yang kamu perbuat untuk dirimu niscaya kamu memperoleh (balasan)nya di sisi Allah sebagai Balasan yang paling baik dan yang paling besar pahalanya. Dan mohonlah ampunan kepada Allah. Sesungguhnya Allah Maha Pengampun lagi Maha Penyayang. (Q.s. a-Muzzammil [73]: 20)

Muqâradah juga masdar dari kata qâradha-yuqâridu-muqâradah (قارض (مقارضة - يقارض dengan menambahkan alif diantara fa fi'il dan 'ain fi'il seperti halnya mudhârabah atau sering juga dipakai dengan sebutan qirâdh dengan mengkasrah-kan fa fi'il-nya yang bermakna al-qath'u yang berarti memotong atau memisahkan. ${ }^{2}$ Karena pemilik harta memang memotong sebagian hartanya un-tuk diberikan kepada orang yang bekerja agar ia usahakan dan memberikan sebagian keuntungannnya.

Dari segi ilmu sharaf, mudhârabah atau muqâradah merupakan fi' iil tsulâtsi mazîd satu huruf bab mufâ'alah, yang biasanya menunjukkan suatu pekerjaan yang saling dilakukan antara dua orang. Ini berarti bahwa mudhârabah atau muqâradah tidak bisa dilakukan seorang diri dalam arti kata, shâhib al-mâl tanpa ada mudhârib tidak berarti, hanya menyebabkan hartanya menganggur, tidak produktif, begitu juga sebaliknya mudhârib tanpa ada shâhib al-mâl tidak ada nilainya. Adanya kerjasama antara keduanya akan mendatangkan suatu keuntungan kepada kedua belah pihak. Itulah bagusnya Islam memberikan keuntung-

\footnotetext{
${ }^{2}$ Abû Luis Ma'luf, Al-Munjid fi al-Lughah wa 'A'lam, (Bayrût: Masyriq, 1986), h. 620.
} 
an kepada kedua belah pihak. ${ }^{3}$

Secara terminologi, banyak ahli fikih yang memberikan definisi di antaranya: Pertama, menurut ulama Hanâbilah:

$$
\text { دفع ماله المى أخر يتجر فيه والربح بينهما4 }
$$

Memberikan harta untuk perdagangan kepada orang lain dan keuntungan (dibagi) pada keduanya.

Kedua, menurut ulama Mâlikiyyah:

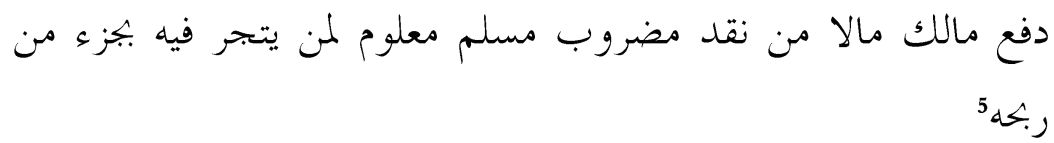

Pemodal memberikan uang dalam jumlah tertentu dan diketahui kepada pedagang dengan (memberikan) bagian dari keuntungan (yang diperoleh).

Ketiga, menurut ulama Hanâfiyyah:

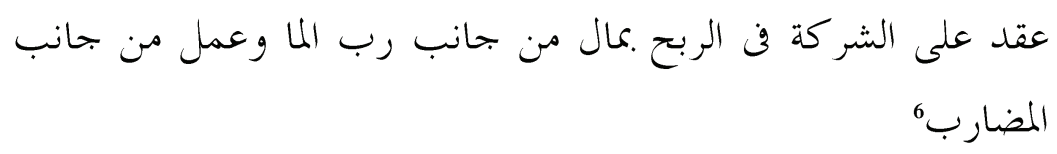

Akad kerja sama untuk mencari keuntungan di mana modal dari pemiliknya dan kerja dari pihak pengusaha.

Keempat, menurut ulama Syâfi'iyyah:

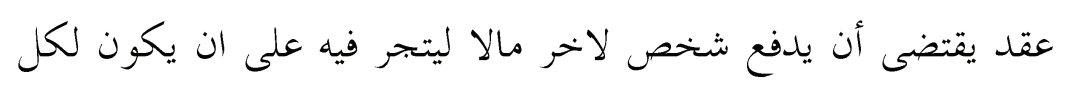

${ }^{3}$ Gusniarti, Obligasi Syariah Mudharabah: Upaya Memahami Obligasi Syariah Mudhârabah Dalam Hukum Islam, Tesis, (Jakarta: UIN Jakarta, 2004), h. 125-135.

${ }^{4}$ Ibn Qudâmah, al-Mughnî, (al-Qâhirah: Dâr al-Manâr, 1367 H), Jilid V, h. 124.

${ }^{5}$ Al-Khatib al-Syaybanî, Mughni al-Mukhtâj, (Bayrût: Dâr al-Fikr, 1994), Jilid II, h. 209.

${ }^{6}$ Hasyiyah ibn ‘Âbidîn, Radd al-Mukhtâr, (Bayrût: Dâr al-Fikr, t.th.), Jilid V, h. 645. 


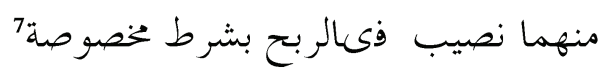

Akad yang menghendaki Seseorang memberikan harta kepada orang lain untuk diperdagangkan dan keduanya mendapat bagian keuntungan yang disepakati bersama.

Kelima, menurut Wahbah al-Zuhaylî dalam kitabnya, al-Fiqh al-Islâmî wa adillatuh, memberikan definisi:

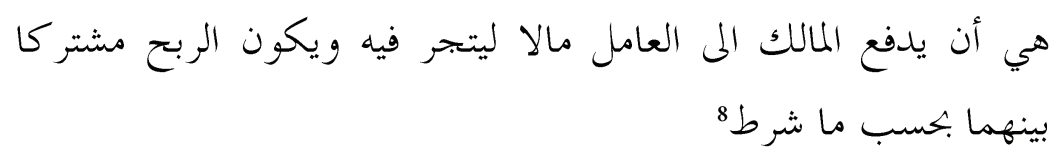

Pemilik harta memberikan harta kepada orang yang bekerja untuk menjalan suatu usaha dan keuntungan dibagi menurut kesepakatan di antara mereka berdua.

Dari pelbagai definisi di atas secara umum tampak tidak ada perbedaan pendapat. Mereka sama-sama mengatakan bahwa di dalam mudhârabah ada dua pihak, yang satu pemodal dan yang lainnya adalah orang yang mempunyai skill untuk mengelola modal yang sudah diberikan dan keuntungannya nanti dibagi sesuai kesepakatan.

Jika kita amati lebih rinci, masing-masing definisi mempunyai kriteria tersendiri. Ulama Hanâfiyah, Hanâbilah, Syâfi'iyah, dan Wahbah al-Zuhaylî secara umum menyatakan bahwa modal yang diberikan kepada pekerja berupa mâl (harta), maknanya lebih umum. Berbeda dengan ulama Mâlikiyyah yang memberi-kan spesifikasi modal berupa nuqud (uang) saja.

Mâl (مال) menurut pengertian ulama Hanafiyah adalah:

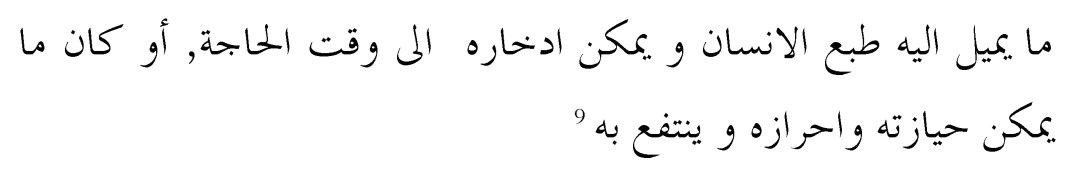

7 'Abd al-Rahnmân al-Juzayrî, Kitâb al-Fiqh 'alâ al-Madzâhib al-Arba'ah, (Bayrût: Dâr al-Kutub al'Ilmiyah, 1990), Juz III, h. 42.

${ }^{8}$ Wahbah al-Zuhaylî, al-Fiqh al-Islâmî wa Adillatuh, (Bayrût: Dâr al-Fikr, 1989), Cet. III, Juz V, h. 3924.

${ }^{9}$ Ibn 'Âbidîn, Radd al-Mukhtâr 'ala al-Durr al-Mukhtâr, (Bayrût: Dâr al-Fikr, t.th.), Jilid III, h. 3. 
Segala yang diminati manusia dan dapat dihadirkan ketika diperlu-kan, dan segala sesuatu yang dapat dimiliki, disimpan dan dapat di-manfaatkan.

Dari definisi di atas tersirat makna bahwa mamfaat bukanlah termasuk harta. Yang termasuk harta hanya yang berbetuk materi. Ini berbeda dengan pendapat jumhur yang mengatakan bahwa mâl tidak saja berbentuk benda tapi juga manfaat dari suatu benda.

Dari pemahaman ulama Hanafiyah tentang harta, dapatlah diketahui bahwa modal yang diberikan oleh shâhib al-mâl kepada mudhârib hanyalah yang berbentuk materi, sedangkan mamfaat seperti penyewaan tidak dapat diberikan. Sedangkan ulama Mâlikiyyah membatasi mâl dengan uang saja.

Begitu juga dengan kerja yang dimaksud untuk memproduktifkan modal, semua ulama selain ulama Hanafiyah membatasi dalam bidang perdagangan saja. Mungkin ini disebabkan pada zaman dahulu usaha mudhârabah yang masih se-derhana banyak dilakukan dalam bidang perdagangan. Seperti yang dikatakan oleh Muhammad 'Abd al-Mu'in Abû Zayd bahwa mudhârabah yang tradisional hanya tertentu dalam bidang perdagangan saja, tapi karena perekonomian semakin maju, maka mudhârabah juga dilaksanakan di bidang lain seperti pertanian, industri, dan pelayanan jasa. ${ }^{10}$ Ini sesuai dengan definisi ulama Hana-fiyah yang tidak membatasi kegiatan mudhârabah dalam bidang perdagangan saja tapi dalam bidang usaha apa yang kira-kira menguntungkan. Karena kegiat-an mudhârabah adalah salah satu kegiatan mu'amalah yang selalu akan berkembang mengikuti perkembangan zaman. Karena itu konsepnya bisa diaktualisasikan dalam bentuk apa saja yang berguna dan bermamfaat sesuai dengan perkembangan sosio-ekonomi setempat.

Dari definisi di atas dapat kita lihat bahwa ada empat unsur yang sangat penting dalam mudhârabah, yaitu: (1) Mudhârabah dilakukan oleh dua pihak; (2) Modal dari pihak shâhib al-mâl dan kerja dari pihak mudhârib; (3) Objek mudhârabah adalah investasi harta; (4) Tujuan mudhârabah adalah perwujudan keuntungan yang dibagi sesuai dengan kesepakatan kedua belah pihak.

Shâhib al-mâl memberikan modalnya kepada mudhârib. Sebagai imbalannya ia akan mendapatkan bagian tertentu dari keuntungan yang diperoleh tetapi jika mengalami kerugian, beban seluruhnya ditanggung oleh shâhib al-mâl. Memang konsekwensi logis dari suatu usaha adalah kemungkinan terjadinya kerugian. Kerugian sebagai risiko usaha ditanggung oleh pemodal kecuali kerugian karena kecerobohan pekerja maka pekerja harus menanggungnya.

${ }^{10}$ Muhammad 'Abd al-Mun'in, al-Mudhârabah wa Tathbiqâtihâ al-'Amaliyyah fi al-Mashârif alIslâmiyah, (Al-Qâhirah: al-Ma'had al-'Aimi li al-Fikr al-Islâmî, 1996), Cet. I, h. 44. 
Jadi dapat disimpulkan bahwa mudhârabah itu adalah suatu akad kerja sama dalam bidang usaha apa saja yang bisa mendatang keuntungan (sesuai dengan ketentuan syariah) karena tujuannya memang untuk mencari keuntungan seperti perdagangan, perindustrian, jasa dan lain lain sesuai dengan perkembangannya, antara dua pihak dimana pihak pertama adalah orang yang mempunyai modal (shâhib al-mâl) dan pihak kedua adalah orang yang mempunyai skill (mudhârib). Keuntungan usaha dibagi menurut kesepakatan dan kerugian ditanggung oleh pemodal selama kerugian bukan disebabkan kelalaian si mudhârib. Shahibul mâl rugi modal dan mudhârib juga tidak menerima jasa apa-apa atas apa yang telah dilakukannya, ia hanya rugi waktu dan tenaga yang telah digunakan. Tapi jika kerugian disebabkan karena kelalaian dan kecerobohan si mudhârib, maka ia harus menggantinya.

Memungkinkan juga kedua pihak mempunyai modal, dari pada melakukan usaha sendiri, akan lebih efektif dan menguntungkan jika mereka bekerja sama. Bisa juga satu pihak yang punya modal tidak tidak mampu, tidak ber-pengalaman atau tidak sempat mengelolanya. Maka pihak kedua yang juga punya modal dengan pengalaman dan keahliannya mengelola kedua modal tersebut. Ini akan membuka pintu untuk bekerja sama dengan pihak ketiga. ${ }^{11}$ Bentuk seperti ini bermanfaat dan tidak ada halangannya dalam syariah. Jika mudhârib dalam perjanjian mudhârabah ini ada beberapa orang, menurut Imam Mâlik, maka keuntungan akan dibagi-bagi untuk mereka sesuai dengan kerja masing-masing. Hal seperti ini sama dengan syirkah abdan. ${ }^{12}$

Ada ulama yang mengatakan bahwa mudhârabah adalah bagian dari syirkah dan ada pula yang membedakannya. Imam Mâlik dan Imam Ahmad ibn Hanbal melihat mudhârabah adalah suatu yang berbeda dengan syirkah. Sedangkan Imam Abû Hanîfah mengesahkan beberapa bentuk mudhârabah yang sama dengan syirkah. ${ }^{13}$ Wahbah al-Zuhaylî, Ibn Rusyd, Taqiy al-Dîn al-Nabhanî dan lainlain menganggap mudhârabah adalah salah satu jenis syirkah.

Hikmah yang dapat dipetik dari akad mudhârabah ini adalah adanya unsur tolong-menolong antara pemilik modal (shâhib al-mâl) dengan pengelola usaha (mudhârib) karena saling memberikan keringanan sehingga terciptalah ukhuwwah islâmiyyah di antara manusia. Terkadang ada orang mempunyai capital tapi

11 Nejatullah M. Siddiq, Partnership and Profit Sharing in Islamic Law, Terj. Fakhriyah Mumtihani, Kemitraan Usaha dan Bagi Hasil dalam Hukum Islam, (Yogyakarta: Dana Bhakti Prima Yasa, 1996), h. 7.

${ }^{12}$ Wahbah al- Zuhaylî, al-Fiqh al-Islâmî wa Adillatuh, h. 3930.

13 Nejatullah M. Siddiq, Partnership and Profit Sharing in Islamic Law, Terj. Fakhriyah Mumtihani, Kemitraan Usaha dan Bagi Hasil dalam Hukum Islam, (Yogyakarta: Dana Bhakti Prima Yasa, 1996), h. 8. 
tidak mempunyai skill untuk memproduktifkannya, sebaliknya ada yang punya skill tapi tidak punya capital. Pemilik modal kadang kala membutuhkan tenaga ahli dalam mengelola modalnya karena dia sendiri tidak mampu mengelolanya atau tidak punya waktu untuk mengelolanya. Sebaliknya pengelola yang mempunyai keahlian dalam bidang usaha juga tidak punya modal. Kedua belah pihak bisa saling membantu dengan melengkapi kekurangan masing-masing. Maka dari itulah diperbolehkannya akad mudhârabah. Ada beberapa dalil yang menggambarkan kebolehan atau bahkan dianjurkan akad mudhârabah ini, yakni: Q.s. al-Muzzammil [62]: 20, Q.s. al-Jumu'ah [73]: 10, dan Q.s. al-Baqarah [2]: 198.

Berikut ini Hadis mengenai mudhârabah, yakni Hadis riwayat Ibn Mâjah dari Shâlih ibn Shuhayb R.a.:

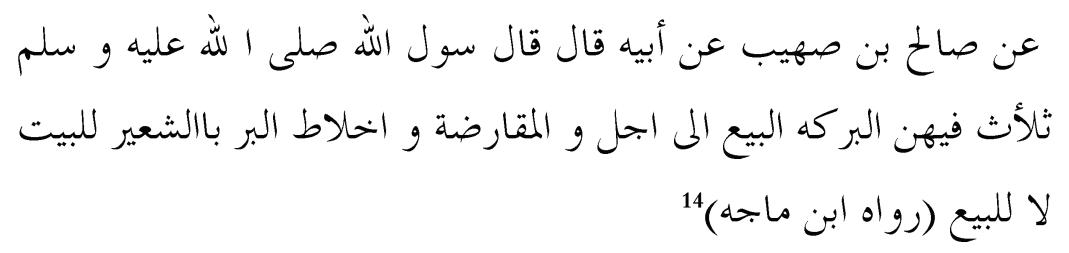

Dari Shâlih ibn Shuhayb bahwa Rasulullah Saw. bersabda, "Tiga hal yang di dalamnya terdapat keberkatan: jual beli secara tangguh, memberi modal, dan mencampur tepung dengan gandum untuk keperluan rumah tangga bukan untuk dijual. (H.R. Ibn Mâjah)

Beberapa dalil di atas menunjukkan bahwa praktik mudhârabah sudah berlangsung sejak awal Islam bahkan sebelum Islam datang (masa Jahiliyyah), karena sebelum Rasulullah Saw. diangkat menjadi Rasul, beliau sendiri pernah pergi ke Syiria untuk berdagang membawa barang dangan milik Khadijah dengan cara mudhârabah ini. Modal berasal dari Khadijah sebagai shâhib al-mâl dan Rasulullah Saw. yang menjalankan usahanya sebagai mudhârib. Selain itu, bentuk-bentuk usaha perdagangan seperti ini sudah berlangsung lama. Karena ini memberi manfaat kepada kedua belah pihak maka Islam melegitimasinya. Shâhib al-mâl dapat memperoleh mamfaat dengan tenaga yang dimiliki oleh mudhârib dan mudhârib juga dapat memperoleh mamfaat dengan harta yang diberikan oleh shâhib al-mâl. Sehingga dengan demikian terciptalah kerja sama antara dua orang yang membutuhkan capital dan skill.

Pada masa 'Umar ibn al-Khaththâb, praktik mudhârabah pun cukup ma-

${ }^{14}$ Muhammad Nashîr al-Dîn al-Bânî, Dha'îf Sunan ibn Mâjah: li al-Imâm al-Hâfizh Abî 'Abd Allâh Muhammad ibn Yazîd al-Qazwayni, (Riyâdh: Maktabah al-Ma'ârif, 1997), h. 178. 
rak. Dalam riwayat Imam Mâlik dan Imam Syâfi'i diceritakan bahwa 'Abd Allâh dan 'Ubayd Allâh (keduanya putra 'Umar) pergi ke Irak untuk ikut dalam pasukan perang. Ketika kembali, mereka bertemu dengan Abû Mûsâ al-Asy'arî (Gubernur Basrah). Abû Mûsâ al-Asy'arî menyambutnya sambil berkata, "Seandainya aku dapat memberi sesuatu yang bermanfaat kepadamu tentu aku akan memberikannya". Kemudian ia berkata lagi, "Di sini ada harta (milik Allah) yang angin aku kirimkan kepada Amîr al-Mu'minîn. Kalau begitu aku aka pinjamkan kepadamu supaya kamu dapat membeli barang di Irak lalu dijual di Madinah. Kalau ada untung silakan ambil dan modalnya kembalikan kepada Amîr al-Mu'minîn". Setelah sampai di Madinah, mereka kembalikan modal kepada "Umar dengan mengambil keuntungannya. Umar tidak membolehkannya dengan pertimbangan, mungkin saja kedua putranya itu memanfaatkan kedudukannya. Tapi 'Ubayd Allâh menjawab, kalau seandainya barang itu rusak mereka akan menjaminnya. Kemudian salah seorang sahabat di samping 'Umar memberikan solusi supaya itu dijadikan sebagai transaksi mudhârabah saja. Umar menyepakatinya dengan mengambil modal dan sebagian keuntungannya dan sisa keuntungan diberikan kepada kedua putranya. ${ }^{15}$ Jadi selain Alquran dan Hadis di atas yang menjelaskan mudhârabah, juga sudah terjadi ijmak ulama tentang kebolehan mudhârabah ini berkenaan dengan kisah Abdullah dan Ubaidillah.

Mudhârabah juga diqiyaskan kepada al-Musaqah yang menjadi kebutuhan manusia antara orang kaya dan fakir. Orang yang punya harta tidak bisa atau tidak sempat mengelola sedangkan orang fakir tidak mempunyai harta, punya kesempatan untuk mengelolanya tanah itu. ${ }^{16}$ Maka disyariatkan akad ini untuk mewujudkan atau mempertemukan dua kepentingan ini.

\section{Rukun dan Syarat Mudhârabah}

Terdapat perbedaan ulama dalam menetapkan rukun dan syarat dari akad mudhârabah ini. Menurut ulama Hanafiyah, rukun mudhârabah hanya dua yaitu: (1) Ijab (ungkapan penyerahan dari shâhib al-mâl). (2) Kabul (ungkapan menerima dari mudhârib). ${ }^{17}$ Jika shâhib al-mâl dan mudhârib sudah melafalkan ijab dan kabul, maka akad tersebut sah karena telah memenuhi rukunnya. Jumhur ulama, menyatakan bahwa rukun mudhârabah ada tiga yaitu: (1) al-'Aqidayn (shâhib al-mâl dan mudhârib). (2) Ma'qûd 'alayh (modal, kerja, dan keuntung-

15 Al-Sayyid Sâbiq, Fiqh al-Sunnah, (Bayrût: Dâr al-Fikr, 1992), Jilid III, h. 212-213; Wahbah alZuhaylî, al-Fiqh al-Islâmî wa Adillatuh, h. 3925-3926.

${ }^{16}$ Wahbah al- Zuhaylî, al-Fiqh al-Islâmî wa Adillatuh, h. 3927.

${ }^{17}$ Wahbah al- Zuhaylî, al-Fiqh al-Islâmî wa Adillatuh, h. 3927 
an). (3) Shîghah (ijab dan kabul) ${ }^{18}$.

Pendapat Imam Syâfi'î sama dengan pendapat jumhur di atas, tapi dia merincinya menjadi lima persyaratan yaitu: harta, kerja, keuntungan, shigah, dua orang yang melakukan akad. ${ }^{19}$ Rukun-rukun selain ijab dan kabul menurut jumhur, dimasukkan oleh ulama Hanafiyah ke dalam syarat-syarat akad mudhârabah. Jadi sebenarnya tidak ada perbedaan di antara mereka.

Adapun syarat-syarat akad mudhârabah menurut jumhur ulama sesuai dengan rukun-rukun di atas adalah: ${ }^{20}$ Pertama, terkait dengan dua orang yang berakad. Dua orang yang melakukan akad haruslah: (a) orang yang cakap untuk mewakilkan; (b) orang yang cakap menjadi wakil.

Pada satu sisi mudhârib yang mengelola modal adalah wakil dari shâhib al-mâl karena ia mengurus harta atas keizinan dan perintah dari pemilik harta sehingga syarat-syarat sebagai wakil juga berlaku bagi mudhârib dalam akad mudhârabah ini. Kedua orang yang berakad tidak disyaratkan beragama Islam, maka boleh saja melakukan kerja sama dengan kafir dzimmî. Namun menurut Mâlikî hukumnya makruh. ${ }^{21}$

Kedua, terkait dengan modal. Ada empat syarat yang terkait dengan modal ini yaitu: Pertama, berbentuk uang. Sepakat ulama tentang kebolehan modal berbentuk dinar atau dirham atau uang yang biasanya digunakan sehari-hari. Tapi ulama berbeda pendapat jika yang dijadikan modal adalah barang dagangan. Ulama yang tidak membolehkan modal berupa barang dagangan baik aqar maupun manqûl dengan alasan bahwa barang perniagaan akan menimbulkan gharar (ketidakjelasan) sehingga modal dan keuntungan menjadi tidak jelas. Nilai dari barang juga hanya diketahui dengan perkiraan. Perkiraan dan sangkaan bisa menimbulkan perbedaan. Perbedaan bisa menimbulkan pertikaian dan pertikaian akan menyebabkan mudhârabah menjadi fâsid. Sedangkan Hanafi dan Hanbali memboleh untuk barang perdagangan manqul yang mitsl (banyak di pasaran) asalkan yang dijadikan sandaran bukan barangnya tapi harga dari barang tersebut karena harga memang dapat dijadikan sebagai modal dalam mudhârabah. Abî Layla dan al-Awza'i membolehkan barang perniagaan berdasarkan nilai barang tersebut. Sedangkan Imam Mâlik dan Imam Syâfi‘i tidak membolehkannya. ${ }^{22}$

\footnotetext{
${ }^{18}$ Wahbah al- Zuhaylî, al-Fiqh al-Islâmî wa Adillatuh, h. 3928.

${ }^{19}$ Wahbah al- Zuhaylî, al-Fiqh al-Islâmî wa Adillatuh, h. 3927- 3928.

${ }^{20}$ Ibn Rusyd, Bidayah al-Mujtahid wa Nihayah al Muqtashid, ( Bayrût: Dâr al-Fikr, t.th.) Jilid II, h. 234.

${ }^{21}$ Wahbah al- Zuhaylî, al-Fiqh al-Islâmî wa Adillatuh, h. 3931-3932.

${ }^{22}$ Ibn Rusyd, Bidâyah al-Mujtahid, h. 178; 'Abd al-Rahmân al-Juzayrî, Kitâb al-Fiqh 'alâ alMadzâhib al-Arba'ah, h. 36 .
} 
Kedua, jumlahnya jelas. Supaya ada perbedaan antara modal yang diperdagangkan dengan keuntungan yang akan dibagikan maka modal harus jelas berapa jumlahnya. Tidak jelasnya jumlah modal menyebabkan keuntungan juga tidak jelas dan akhirnya akad mudhârabah menjadi tidak sah. Karena kejelasan keuntungan merupakan salah satu syarat dari akad mudhârabah. ${ }^{23}$

Ketiga, tunai. Akad mudhârabah tidak sah kalau modal masih dalam bentuk utang atau tidak ada ditempat yang akan menyebabkan akad mudhârabah menjadi fâsid. Ini adalah Ittifaq ulama. Jika modal modal dalam bentuk utang dari mudhârib, maka mudhârib tetap berutang, keuntungan yang ia dapat menjadi miliknya dan kerugian ditanggung juga olehnya. Begitu juga jika utang itu ada pada pihak lain, maka utang harus diserahkan dahulu orang yang memberikan utang (shâhib al-mâl) kemudian baru diserahkan kepada mudhârib menurut ulama Mâlikiyyah, Syâfi‘iyah dan Hanabilah. ${ }^{24}$

Keempat, diserahkan sepenuhnya kepada mudhârib. Shâhib al-mâl harus melepaskan kekuasaannya terhadap modal yang diberikan kepada mudhârib. Jika masih dalam kuasanya, bagaimana mudhârib akan mengelolanya karena geraknya akan terbatas. Jika modal tersebut merupakan titipan (wadi'ah) shâhib almâl kepada mudhârib, maka boleh dijadikan sebagai modal mudhârabah. Berbeda pendapat ulama jika modal itu tidak diserahkan seluruhnya oleh shâhib almâl, menurut ulama Hanafiyah, Mâlikiyyah dan Syâfi‘iyah, akad mudhârabahnya tidak sah. Akan tetapi menurut ulama Hanabilah boleh saja asal tidak mengganggu kelancaran usaha tersebut. ${ }^{25}$

Ketiga, terkait dengan keuntungan. Keuntungan disyaratkan: Pertama, pembagiannya jelas. Keuntungan adalah tujuan akhir dari mudhârabah. Ketidakjelasan keuntungan menyebabkan mudhârabah menjadi fâsid. Ini menurut ulama Hanafiyah, jika pembagian keuntungan tidak jelas maka mudhârabah menjadi fâsid yang berarti syarat batal. Meskipun syarat batal, akad tetap sah. Maka harus jelas berapa bagiannya misalnya $1 / 2,1 / 3$, atau $1 / 4$ sesuai kesepakatan dari keuntungan.

Kedua, keuntungan diambil dari hasil usaha tersebut. Bagian masing-masing diambil dari keuntungan dagang tersebut dalam arti kata keuntungan tidak boleh diambil dari selain proyek yang didanai oleh modal tadi. ${ }^{26}$

Secara umum, syarat-syarat yang tidak diperbolehkan semua fukaha adalah syarat-syarat yang dapat menyebabkan terjadinya gharar. Tidak ada perbe-

\footnotetext{
${ }^{23}$ Al-Sayyid Sâbiq, Fiqh al-Sunnah, h. 213.

${ }^{24 ،}$ Abd al-Rahmân al-Juzayrî, Kitâb al-Fiqh 'alâ al-Madzâhib al-Arba'ah, h. 36.

${ }^{25}$ Wahbah al- Zuhaylî, al-Fiqh al-Islâmî wa Adillatuh, h. 3935.

${ }^{26}$ Wahbah al- Zuhaylî, al-Fiqh al-Islâmî wa Adillatuh, h. 3937 -3938.
} 
daan pendapat dikalangan ulama tentang ketidaksahannya jika salah satu pihak mensyaratkan penambahan keuntungan untuk dirinya dari apa yang sudah ditetapkan dalam perjanjian. Karena hal ini menyebabkan apa yang sudah disepakati dalam qirâdh memjadi majhul (tidak diketahui). ${ }^{27}$

Bila rukun dan syarat sudah terpenuhi, maka mudhârabah dipandang sah. Sebaliknya, bila rukun dan syarat tidak terpenuhi maka mudhârabah dipandang tidak sah. Bila salah satu syarat tidak terpenuhi, maka mudhârabah dipandang rusak (fâsid). Dalam kondisi mudhârabah fâsid, menurut Ibn Rusyd, posisi mudhârib tidak sebagaimana layaknya mudhârib yang berhak atas keuntungan, tetapi beralih sebagai orang yang berhak menerima upah. ${ }^{28}$

Ulama Hanafiyah juga membagi bentuk mudhârabah kepada mudhârabah Sahihah (mudhârabah yang sah) dan mudhârabah fâsidah (mudhârabah yang rusak) berdasarkan syarat-syarat di atas, Jika yang terjadi mudhârabah fâsid, maka mudhârib hanya berhak mendapatkan upah kerja sesuai dengan upah yang berlaku di daerah itu, sedangkan seluruh keuntungan menjadi pemilik shâhib almâl. Ini adalah pendapat Ulama Hanafiyah, Syâfi'iyah dan Hanâbilah tetapi menurut Mâlikiyyah, status pekerja tetap sebagai mudhârib yang berhak mendapatkan keuntungan ${ }^{29}$

Secara umum memang tidak ada perbedaan pendapat ulama, tapi mengenai perinciannya masih terjadi khilafiah di antara mereka, misalnya dalam hal orang yang bekerja mensyaratkan semua keuntungan untuk dirinya. Imam Mâlik membolehkannya, tetapi Imam Syâfi'i tidak membolehkannya dan akad mudhârabah menjadi fâsid. Sedangkan menurut Abu Hanifah dan Hanbali, akad mudhârabah (qirâdh) berubah menjadi akad qardh (utang-piutang). ${ }^{30}$ Karena qirâdh juga datang dari makna qardh.

Dalam kondisi di mana pemilik harta mensyaratkan kerugian ditanggung oleh orang yang bekerja (mudhârib). Maka menurut Imam Mâlik dan Imam Syâfi'i, tidak boleh dan menjadi mudhârabah yang fâsid karena menambah kesamaran dalam akad qirâdh hingga menjadi rusak. Imam Abû Hanîfah dan pengikut-pengikutnya membolehkan tetapi syaratnya batal karena ini sama dengan syarat yang rusak dalam jual beli bahwa jual belinya sah tetapi syaratnya batal. ${ }^{31}$

\footnotetext{
${ }^{27}$ Ibn Rusyd, Bidâyah al-Mujtahid, h. 179.

${ }^{28}$ Ibn Rusyd, Bidâyah al-Mujtahid, h. 234.

${ }^{29}$ Ibnu Qudamah, al-Mugnî, (al-Qâhirah: Dâr al-Manâr, 1367 H), Jilid V, h. 30.

${ }^{30}$ Ibn Rusyd, Bidâyah al-Mujtahid, h. 179.

${ }^{31}$ Ibn Rusyd, Bidâyah al-Mujtahid, h. 180.
} 


\section{Keutamaan Obligasi Mudhârabah}

Pertama, obligasi mudhârabah merupakan instrumen investasi yang memungkinkan pengembangan dana dalam bentuk penyertaan dana dalam berbagai unit dengan nilai yang sama dalam bentuk obligasi tercatat yang mencerminkan kepemilikan atas aset, dengan kata lain obligasi mudhârabah adalah kontrak pembiayaan pemodal dengan pemilik proyek/perusahaan dengan ketentuan pemilik peroyek/perusahaan dapat menggunakan dana tersebut dengan memberikan keuntungan yang telah disetujui pada saat emisi obligasi

Kedua, obligasi mudhârabah harus mencerminkan kepemilikan pemodal sebagai ikatan untuk membiayai proyek/pengembangan usaha pada perusahaan secara spesifik, pemegang obligasi berhak atas kepemilikan yang berhubungan dengan proyek/perusahaan meliputi penjualan, hadiah, hipotek, dan semacamnya. kontrak dalam obligasi muqarodoh terbentuk akibat penawaran umum dari pihak issuer kepada pemodal kontrak tersebut harus sesuai dengan syaria'ah dalam bentuk transaksi dan murabahahnya serta pembagian bagi hasilnya.

Ketiga, setelah habis masa obligasinya (matury date) pemilik obligasi akan menerima pokok modalnya atau mengkonversikan kepada surah berharga lainnya.

Skema transaksi obligasi mudhârabah

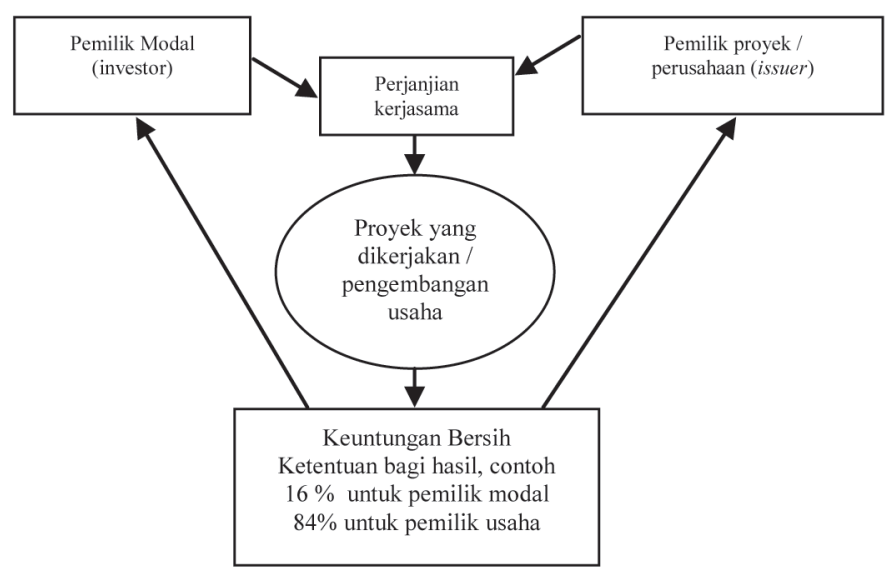

Penentuan harga obligasi mudhârabah adalah jumlah present value aliran bagi hasil ditambah present value nilai nominal. Contoh: Berapakah harga obligasi mudhârabah bernilai nominal Rp 10 juta dengan tingkat bagi hasil 16\% dan jatuh tempo 3 tahun? Dan investor mensyaratkan tingkat bagi hasil 18\%. Jawab: Harga nominal $=16 \% \times \operatorname{Rp~10.000.000~}=\operatorname{Rp~1.600.000.~Harga~}=\operatorname{Rp~1.600.000:~}$ 
$(1+18 \%)+\operatorname{Rp} 1.600 .000:(1+18 \%)^{2}+\operatorname{Rp} 1.600 .000:(1+18 \%)^{3}+\operatorname{Rp} 10.000 .000:$ $(1+18 \%)^{3}=\operatorname{Rp} 9.565 .260$.

Nominal yield adalah bagi hasil obligasi yang besarnya sama dengan tingkat bagi hasil (profit sharing rate) dikalikan dengan nilai nominalnya. Tingkat bagi hasil obligasi merefleksikan tingkat bagi hasil yang mengandung komponenkomponen tingkat pertumbuhan ekonomi, tingkat inflasi dan risiko. Penentuan tingkat bagi hasil didasarkan atas tingkat bagi hasil perbankan dan tingkat keuntungan issuer yang sedang berlaku, biasanya tingkat bagi hasil obligasi di atas tingkat bagi hasil perbankan. Penetapan tingkat bagi hasil (profit sharing rate) di atas tingkat bagi hasil perbankan dimaksudkan sebagai premi risiko, premi risiko ini penting karena untuk merekompensasi kemungkinan beberapa risiko investasi obligasi.

Pembayaran bagi hasil dapat dilakukan setiap tahun (annual) atau semester (semiannual) atau triwulan, untuk perhitungan bagi hasil harus disesuaikan dengan peride pembayaran bagi hasil yang diberlakukan. Pendapatan bagi hasil = tingkat bagi hasil (\%) x nilai nominal. Contoh: PT Lintas Data Utama menerbitkan obligasi mudhârabah dengan nominal Rp 10.000.000 dengan tingkat bagi hasil $18 \%$ per tahun. Berapakah bagi hasil yang dibayarkan jika pembayarannya dilakukan setiap a). Tahun b). Semester c). Triwulan .

Jawab: Pendapatan bagi hasil=tingkat bagi hasil (\%) x nilai nominal. (a) Pendapatan bagi hasil $=18 \%$ x Rp $10.000 .000=$ Rp 1.800.000. (b) Pendapatan bagi hasil $=\operatorname{Rp} 1.800 .000: 2=\operatorname{Rp} 900.000$. (c) Pendapatan bagi hasil $=R p 1.800 .000$ $: 4=\operatorname{Rp} 450.000$.

\section{Obligasi ljârah}

Al-Ijârah berasal dari kata al-ajr yang berarti al-iwadh (ganti). Dari sebab itu, al-tsawâb (pahala) dinamai ajr (upah). Menurut pengertian Syara, al-ijârah ialah suatu jenis akad untuk mengambil manfaat dengan jalan penggantian. Karena itu menyewakan pohon untuk dimanfaatkan buahnya, tidaklah sah, karena pohon bukan sebagai manfaat. Demikian pula halnya makanan untuk dimakan, barang yang dapat ditakar dan ditimbang. Karena jenis-jenis barang ini tidak dapat dimanfaatkan kecuali dengan menggunakan barang itu sendiri.

Begitu juga menyewakan sapi, atau domba, atau unta untuk diambil susunya. Karena penyewaan adalah pemilikan manfaat. Sedangkan dalam keadaan seperti ini, berarti pemilikan susu, padahal ia adalah 'ain (barangnya) itu sendiri. Akad menghendaki pengambilan manfaat, bukan barangnya itu sendiri.

Manfaat, terkadang berbentuk manfaat barang, seperti rumah untuk ditempati, atau mobil untuk dikendarai. Dan terkadang berbentuk karya, seperti karya 
seorang insinyur bangunan, tukang tenun, tukang pewarna (celup), penjahit dan tukang binatu. Terkadang manfaat itu berbentuk sebagai keria pribadi seseorang yang mencurahkan tenaga, seperti khadam (pembantu) dan para pekerja.

Pemilik yang menyewakan manfaat disebut Mu'ajjir (orang yang menyewakan). Pihak lain yang memberikan sewa disebut Musta'jir (orang yang menyewa $=$ penyewa). Dan, sesuatu yang diakatakan untuk diambil manfaatnya disebut Ma'jur (sewaan). Sedangkan jasa yang diberikan sebagai imbalan manfaat disebut Ajrah atau Ujrah (upah). Manakala akad sewa-menyewa telah berlangsung, penyewa sudah berhak mengambil manfaat. Dan orang yang menyewakan berhak pula mengambil upah, karena akad ini adalah mu'âwadhah (penggantian).

Sewa-menyewa disyariatkan berdasarkan Alquran, Sunah, dan Ijmak. Allah berfirman pada surah al-Zukhruf ayat 32:

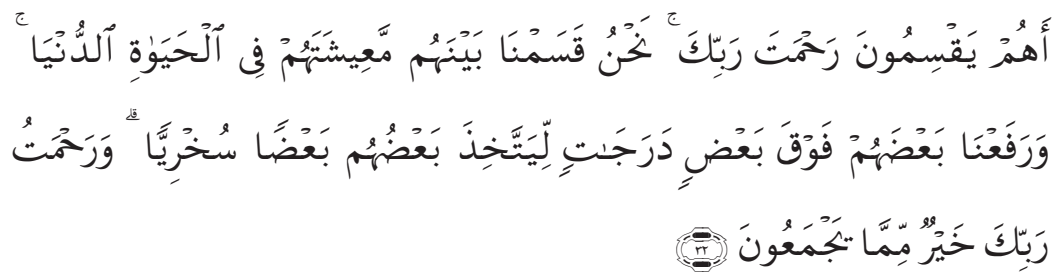

Apakah mereka yang membagi-bagi rahmat Tuhanmu? Kami telah menentukan antara mereka penghidupan mereka dalam kehidupan dunia, dan Kami telah meninggikan sebagian mereka atas sebagian yang lain beberapa derajat, agar sebagian mereka dapat mempergunakan yang lain. Dan rahmat Tuhanmu lebih baik dari apa yang mereka kumpulkan". (Q.s. al-Zukhruf [43]: 32)

Firman Allah surah al-Baqarah ayat 233:

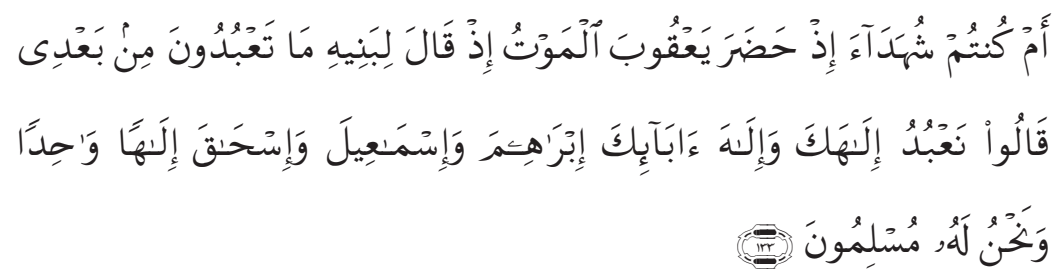

Para ibu hendaklah menyusukan anak-anaknya selama dua tahun penuh, Yaitu bagi yang ingin menyempurnakan penyusuan. dan kewajiban ayah 
memberi Makan dan pakaian kepada Para ibu dengan cara ma'ruf. Seseorang tidak dibebani melainkan menurut kadar kesanggupannya. Janganlah seorang ibu menderita kesengsaraan karena anaknya dan seorang ayah karena anaknya, dan warispun berkewajiban demikian. apabila keduanya ingin menyapih (sebelum dua tahun) dengan kerelaan keduanya dan permusyawaratan, Maka tidak ada dosa atas keduanya. dan jika kamu ingin anakmu disusukan oleh orang lain, Maka tidak ada dosa bagimu apabila kamu memberikan pembayaran menurut yang patut. bertakwalah kamu kepada Allah dan ketahuilah bahwa Allah Maha melihat apa yang kamu kerjakan. (Q.s. al-Baqarah [2]: 233)

Al-Bukhârî meriwayatkan, bahwa Nabi Saw. pernah menyewa seseorang dari bani al-Dîl bernama 'Abd Allâh ibn al-Urayqith. Orang ini petunjuk jalan yang profesional. Juga diriwayatkan oleh Ibn Mâjah, bahwa Nabi Saw. bersabda:

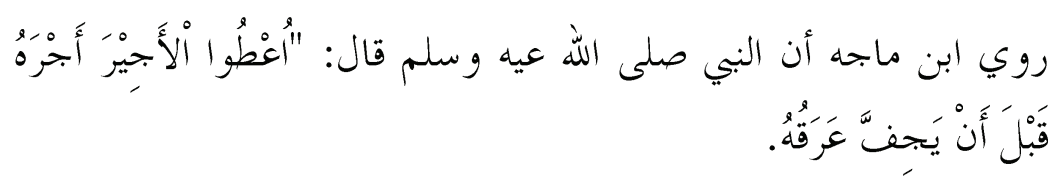

Berikanlah olehmu upah orang sewaan sebelum keringatnya kering.

Ahmad, Abû Dâwud, dan al-Nasa'i meriwayatkan dari Said ibn Abî Waqqâsh R.a., ia berkata:

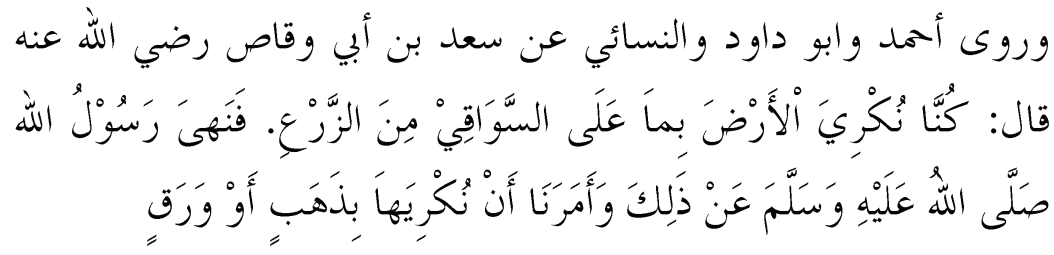

Dahulu kami menyewa tanah dengan (jalan membayar dari) tanaman yang tumbuh. Lalu Rasulullah melarang kami cara itu dan memerintahkan kami agar membayarnya dengan uang emas atau perak.

Al-Bukhârî dan Muslim meriwayatkan dari Ibnu Abbas, bahwa Nabi saw., bersabda:

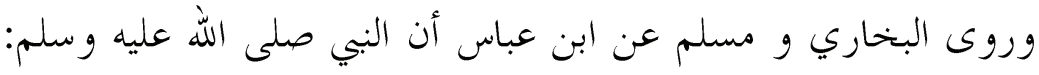




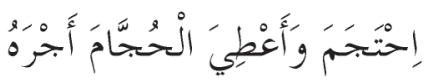

Berbekamlah kamu, kemudian berikanlah olehmu upahnya kepada tukang bekam itu .

Mengenai disyari'atkan ljârah, semua umat bersepakat, tak seorang ulama pun yang membantah kesepakatan (ijma) ini, sekalipun ada beberapa orang di antara mereka yang berbeda pendapat, akan tetapi hal itu tidak dianggap.

Ijârah disyari'atkan, karena manusia menghajatkannya (memerlukannya). Mereka membutuhkan rumah untuk tempat tinggal, sebagian mereka membutuhkan sebagian lainnya, mereka butuh kepada binatang untuk kendaraan dan angkutan, membutuhkan pelbagai peralatan untuk digunakan dalam kebutuhan hidup mereka membutuhkan tanah untuk bercocok tanam.

\section{Syarat Sah ljârah}

Untuk sahnya Ijârah diperlukan syarat sebagai berikut: Pertama, kerelaan dua pihak yang melakukan akad. Kalau salah seorang dari mereka dipaksa untuk melakukan ijârah, maka tidak sah, berdalil kepada firman Allah yang artinya:

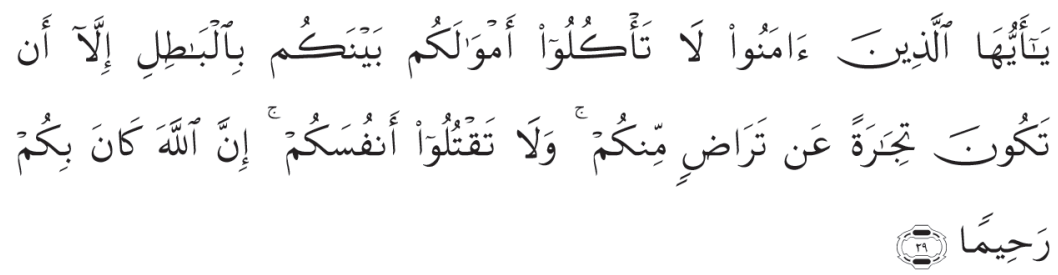

Hai orang-orang yang beriman, janganlah kamu saling memakan harta sesamamu dengan jalan yang batil, kecuali dengan jalan perniagaan yang Berlaku dengan suka sama-suka di antara kamu. dan janganlah kamu membunuh dirimu[287]; Sesungguhnya Allah adalah Maha Penyayang kepadamu. (Q.s. al-Nisâ' [3]: 29)

Kedua, mengetahui manfaat dengan sempurna barang yang diakadkan, sehingga mencegah terjadinya perselisihan. Dengan jalan menyaksikan barang itu sendiri, atau kejeasan sifat-sifatnya jika dapat hal ini dilakukan, menjelaskan masa sewa, seperti sebulan atau setahun atau lebih atau kurang, serta menjelaskan pekerjaan yang diharapkan. 
Ketiga, hendaklah barang yang menjadi obyek termasuk (akad) dapat dimanfaatkan kegunaanya menurut kriteria, realita dan syarak. Sebagian di antara para ulama fikih ada yang membebankan persyaratan ini, untuk itu ia berpendapat, bahwa menyewakan barang yang tidak dapat dibagi (tidak dalam keadaan lengkap), hukumnya tidak boleh, sebab manfaat kegunaannya tidak dapat ditentukan. Pendapat ini adalah pendapat Mazhab Abû Hanîfah dan sekelompok ulama. Akan tetapi jumhur ulama (mayoritas para ulama ahli fikih) mengatakan bahwa menyewakan barang yang tidak dapat dibagi dalam keadaan utuh secara mutlak: diperbolehkan, apakah dari kelengkapan aslinya atau bukan. Sebab barang yang dalam keadaan tidak lengkap itu termasuk juga dapat dimanfkatkan dan penyerahannya dapat dilakukan dengan mempretelinya atau dengan cara mempersiapkannya untuk kegunaan tertentu, sebagaimana hal ini juga diperbolehkan dalam masalah transaksi jual beli.

Dan transaksi sewa-menyewa itu sendiri adalah salah satu di antara kedua jenis transaksi jual beli. Dan apabila manfaat (barang yang dipreteli itu) masih belum jelas kegunaannya, maka transaksi sewa-menyewanya tidak sah alias batal.

Keempat, dapat diserahkannya sesuatu yang disewakan berikut kegunaan (manfaatnya). Maka tidak sah penyewaan binatang yang buron (dalam pencarian) dan tidak sah pula binatang yang lumpuh, karena tidak dapat diserahkan. Beg-itu juga tanah pertanian yang tandus dan binatang untuk pengangkutan yang lumpuh, karena tidak mendatangkan kegunaan yang menjadi obyek dari akad ini.

Kelima, bahwa manfaat, adalah hal yang mubah, bukan yang diharamkan. Maka tidak sah sewa-menyewa dalam hal maksiat, karena maksiat wajib ditingalkan. Orang yang menyewa seeorang untuk membunuh seseorang secara aniaya, atau menyewakan rumahnya kepada orang yang menjual khamar atau untuk digunakan tempat main judi atau dijadikan gereja, maka menjadi ijârah fâsid. Demikian juga memberi upah kepada tukang ramal dan tukang hitunghitung dan semua pemberian dalam rangka peramalan ${ }^{32}$ dan perhitungan, ${ }^{33}$ karena upah yang ia berikan adalah penggantian dari hal yang diharamkan dan termasuk ke dalam kategori memakan uang manusia dengan batil.

Obligasi ijârah (ijârah bond) merupakan bentuk transaksi obligasi dengan sistem pemilik modal menyewakan modalnya dalam bentuk sekuritas yang

\footnotetext{
${ }^{32}$ Orang yang meramalkan berita-berita yang bakal terjadi di masa datang dan ia mengakui rahasia-rahasia.

${ }^{33}$ Adalah orang yang mengakui bahwa dirinya mengetahui barang-barang yang dicuri dan mengetahui di mana barang yang hilang berada.
} 
kemudian digunakan oleh emiten untuk membiayai proyek atau mengembangkan perusahaan dengan memberikan harga sewa dan masa penyewaan yang telah disepakati dengan kontrak didepan. Keuntungan yang diperoleh oleh pemilik modal dengan menerima sewa atas sekuritas yang dimiliknya dan keuntungan bagi penyewa mendapatkan sekuritas dalam bentuk dana segar yang dapat digunakan kapan pun.

Penentuan harga untuk obligasi ijârah dapat menggunakan model Zero profit sharing bond yaitu pemilik menyewakan modalnya dalam bentuk obligasi yang diterbitkan oleh emitten dengan nominal yang telah ditentukan, pemilik modal dan emiten melakukan kontrak sewa dengan menentukan kapan habisnya masa sewa dan jumlah harga sewa yang harus dibayar. Keuntungan pemilik modal mendapatkan pembayaran sewa dengan mendiskonto harga obligasi terhadap nominal di depan, dan emiten tidak diharuskan memberikan bagi pemegang obligasi ijârah tetapi harus mengembalikan aset yang disewanya ketika masa sewanya telah habis. Adapun skema obligasi ijârah adalah sebagai berikut:

Skema obligasi ijârah

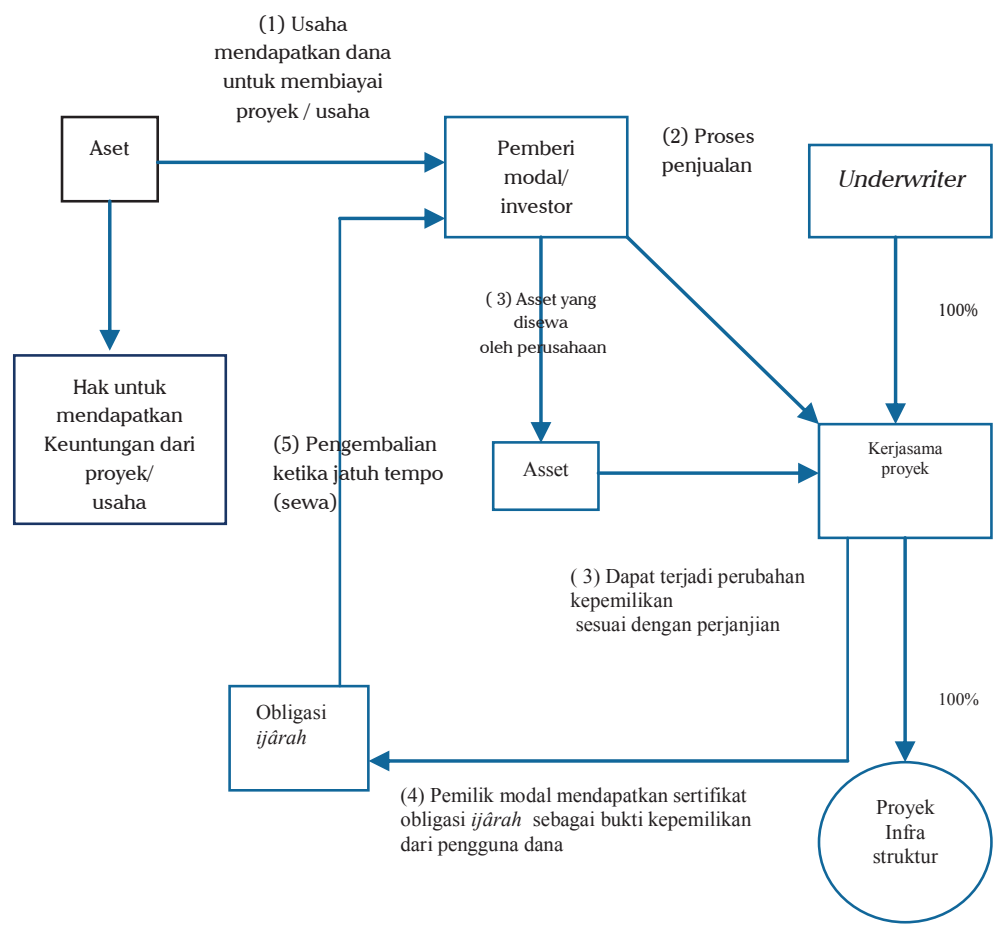


Harga obligasi ijârah non profit sharing dengan menggunakan model Zero profit sharing bond atau pure profit sharing bond adalah: Harga obligasi ijârah pure profit sharing bond $=$ nilai nominal : $(1+\text { harga sewa })^{\mathrm{n}}$

Contoh: Sebuah obligasi ijârah dengan nominal Rp 1.000.000 dengan masa sewa 5 tahun dijual dengan harga Rp 425.000 maka tingkat keuntungan harga sewanya dapat ditentukan sebagai berikut: Harga obligasi ijârah non profit sharing bond = nilai nominal : $(1+\mathrm{hs})^{\mathrm{n} \cdot} \operatorname{Rp} 425.000=\operatorname{Rp} 1.000 .000:(1+\mathrm{hs})^{5}(1$ $+\mathrm{hs})^{5}=0,425$. Tingkat keuntungan harga sewa $=18,5 \%$. Selain cara di atas maka dapat digunakan penentuan harga ijârah pure bond dengan model: Harga $=$ nilai nominal $:(1+r)^{t}$, dengan $r=$ tingkat bagi hasil dan $\mathrm{t}=$ jangka waktu sewa

Tetapi karena kenyataanya tingkat bagi hasil berfluktuasi maka harga obligasi ijârah non profit sharing bond adalah $\mathrm{p}=$ nominal : $\left\{\left(1+\mathrm{r}_{1}\right)\right.$ $\left.\left(1+E\left[r_{2}\right]\right)\left(1+E\left[r_{3}\right]\right)\left(1+E\left[r_{4}\right]\right)\left(1+E\left[r_{5}\right]\right)\left(1+E\left[r_{t}\right]\right)\right\}$ di mana $r_{t}=$ tingkat bagi hasil saat ini, $E\left[r_{2}\right], E\left[r_{3}\right], E\left[r_{4}\right], E\left[r_{5}\right]$ adalah perkiraan tingkat bagi hasil pada tahun ke $2,3,4,5$, sedangkan $\mathrm{E}\left[\mathrm{r}_{\mathrm{t}}\right]=$ perkiraan tingkat bunga pada tahun $\mathrm{t}$ dan $\mathrm{t}=$ waktu habisnya sewa.

Sebuah obligasi ijârah non profit sharing dengan nilai nominal Rp 10 juta dan dengan masa sewa 3 tahun, tingkat bagi hasil tetap 16\% berapakah harga obligasi tersebut? Jika obligasi ijârah non profit sharing dengan nominal yang sama dengan masa sewa 5 tahun dan tingkat bagi hasil pada tahun ke-4 dan 5 adalah 15,5\%, berapakah harga obligasi tersebut? Jawab: Kasus pertama adalah obligasi ijârah non profit sharing dengan nominal 10 juta dengan masa sewa 3 tahun, tingkat bagi hasil tetap 16\%. Harganya $=\mathrm{Rp} 10.000 .000:(1+16 \%)^{3}=\mathrm{Rp}$ 6.410.250 (dibulatkan).

Kasus kedua adalah obligasi ijârah non profit sharing dengan nominal Rp 10.000.000 dengan masa sewa 5 tahun, tingkat bagi hasil tetap tahun ke-1-3 = $16 \%$ dan tahun ke-4 dan $5=15,5 \%$ maka harganya $=\operatorname{Rp} 10.000 .000:(1+16 \%) \mathrm{x}$ $(1+16 \%) \times(1+16 \%) \times(1+15,5 \%) \times(1+15,5 \%)=4.805 .380$ (dibulatkan)

Kasus ketiga: Bagaimanakah harga obligasi ijârah non profit sharing dengan nilai Rp 10.000.000 dan dengan masa sewa 3 tahun dan tingkat bagi hasil tetap 15,5\%. Jawab: Harga $=$ Rp $10.000 .000:(1+15,5 \%) \times(1+15,5 \%) \times(1+15,5 \%)$ $=\operatorname{Rp} 6.489 .290$ (dibulatkan)

Dari perhitungan di atas, bandingkan harga obligasi ijârah non profit sharing dengan nominal Rp 10 juta dengan masa sewa 3 tahun serta tingkat bagi hasil tetap 16\% (Rp 6.410.250), dan obligasi ijârah non profit sharing dengan masa sewa yang sama tetapi tingkat bagi hasil lebih rendah yaitu $15,5 \%$ (Rp 6.489.290) hasilnya meunjukan bahwa tingkat bagi hasil berhubungan terbalik 
dengan obligasi ijârah non profit sharing. Pada saat tingkat bagi hasil mengalami penurunan harga obligasi mengalami apresiasi.

\section{Karakteristik obligasi ijârah}

Karakteristik obligasi ljârah secara nature berasal dari hubungan kerjasama dalam kontrak sewa, sebagai berikut. Pertama, Ijârah obligasi adalah surah-surah berharga yang mewakili kepemilikan dan menggambarkan aset yang dikenal dan ada, yang diikat dengan suatu kontrak sewa. Dengan maksud bahwa obligasi ijârah dapat diperjual belikan di pasar modal dengan harga yang ditentukan oleh kekuatan pasar. kondisi pasar secara umum mempengaruhi ekonomi dan pasar uang, opportunity cost (arus kas dan harapan memperoleh keuntungan atas pembiayaan baru), harga riil aset yang diinvestasikan dan kecenderungan pasar yang spesifik berhubungan dengan surah-surah berharga dan obligasi Ijârah. obligasi ijârah juga terpengaruh oleh risiko yang berhubungan dengan kesanggupan penyewa untuk membayar harga sewa yang telah disepakati dan risiko yang timbul pada harga aset yang disewakan serta biaya penjaminan dan pemeliharaan lainnya.

Kedua, pengharapan atas tingkat keuntungan bersih tidak dapat ditentukan dengan pasti karena adanya biaya perawatan dan asuransi terhadapt aset yang disewakan sebagai konsekuensi atas kontrak sewa. Ketiga, obligasi ijârah dapat diperjual belikan sesuai dengan mekanisme pasar di pasar modal. Keempat, obligasi ijârah menawarkan suatu bentuk sekuritas yang fleksible dari segi kelayakn pasar dan manjemen emisi, pemerintah, perusahaan swasta atau negara dapat mengeluarkan obligasi ijârah yang dapat dimiliki oleh pemilik modal dalam bentuk sekuritas, dan pemegang obligasi ijârah harus memelihara asetnya dan mengasuransikan terhadap sekuritas yang ia miliki oleh karena itu pemegang obligasi ijârah berhak memperoleh keuntungan yang bagus pula

\section{Obligasi Musyârakah}

Secara bahasa syirkah berarti ikhtilâth (pencampuran) yakni bercampurnya satu harta dengan harta yang lain, yaitu konsep dan mekanisme dasar usaha kerjasama investasi berbagi laba dan rugi, yang dalam kosakata fikih klasik dikenal dengan istilah syirkah, yang secara etimologi berarti percampuran (al-ikhtilâth) sedangkan menurut terminologinya adalah:

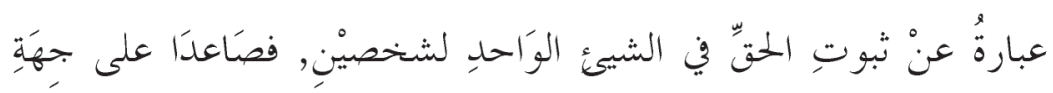




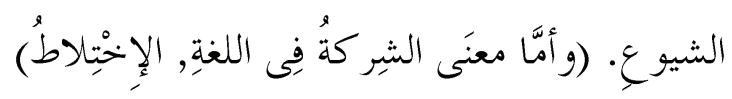

Suatu perumpamaan tentang ketetapan hak kepemilikan bagi dua orang (yang sepakat bekerjasama dalam suatu usaha) untuk mengambil bagian dalam proporsi yang sama sesuai dengan besarnya perbandingan (modal usaha). ${ }^{34}$

Dasar konsep tersebut di atas adalah sabda Rasulullah dalam sebuah Hadis Kudsi yang diriwayatkan oleh Abû Dâwûdan al-Hâkim:

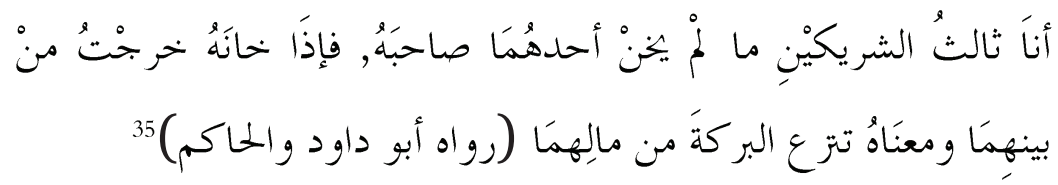

Aku adalah ketiga dari dua orang yang bersyarikat, selama salah satunya tidak menghianati kawannya, namun jika salah satunya menghianati kawannya maka Aku akan keluar dari antara mereka berdua." Maksudnya di sini adalah hilangnya "barakah" harta yang disertakan oleh keduanya.

(H.r. Abû Dâwûd dan Hâkim)

Selanjutnya jumhur ulama mempergunakan kata syarika' untuk model teransaksi tertentu, meski tidak ada percampuran dua bagian karena terjadinya sebuah transaksi yang menjadi sebab terjadinya percampuran harta. ${ }^{36}$

Ada perbedaan pendapat di kalangan ulama dalam mendifinisikan syirkah secara terminologi syarî. Mâlikiyyah mengatakan bahwa syirkah adalah pemberian wewenang kepada pihak-pihak yang bekerja sama, artinya setiap pihak memberikan wewenang kepada patnernya atas harta yang dimiliki bersama dengan masih sahnya wewenang atas harta masing-masing. ${ }^{37}$ Madzhab Hanbalî berpendapat bahwa syirkah adalah pencampuran dalam kepemilikan dan wewenang. ${ }^{38}$ Syâfi'iyyah mengatakan, syirkah adalah tetapnya hak kepemilikan bagi

\footnotetext{
${ }^{34}$ Al-Mawardi, Kifâyah al-Ahyâr, Juz I, (Semarang: Maktab al-'Alawiyyah, t.th.,). h. 280.

${ }^{35}$ Al-Mawardi, Kifâyah al-Ahyâr, h. 280.

${ }^{36}$ Muhammad ibn 'Abd al-Wâhid, Syarh Fath al-Qâdir Ma'a al-Inâyah, (Bayrût: Dâr al-Fikr, t.th),
} Jilid V, h. 2.

${ }^{37}$ Ahmad al-Dardirî Abû al-Barakât, al-Syarh al-Kabîr ma‘a Hâsiyyah al-Dasûqî, (Bayrût: Dâr alFikr, t.th), Jilid III, h. 348.

38 'Abd Allâh ibn Ahmad Ibn Qudâmah, al-Mughnî, (Bairut: Dar el Fikr, 1405 H), Jilid V, h. 1. 
dua pihak atau lebih. ${ }^{39}$

Hanafiyyah berkata syirkah transaksi yang dilakukan dua pihak dalam hal permodalan dan keuntungan. ${ }^{40}$ Definisi yang dikemukakan oleh Hanafiyyah yang paling tepat karena mengungkapkan hakikat syirkah adalah sebuah transaksi.

\section{Rukun dan Syarat Syirkah}

Menurut Jumhur ulama ada tiga rukun yang harus dipenuhi dalam melaksanakan usaha syirkah, yaitu: (a) Adanya pihak-pihak yang melakukan transaksi; (b) Adanya real aset (barang atau jasa) sebagai objek transaksi; (c) Shighah (ijab dan kabul) ${ }^{41}$.

Sedangkan syarat-syarat yang harus dipenuhi baik dalam hal syarat pihak yang melakukan transaksi ataupun obyek transaksi antara lain adalah: (a) Cakap hukum; (b) Jumlah nisbah keuntungan harus diketahui; (c) Jumlah keuntungan tidak boleh ditentukan secara nominal; (d) Modal syirkah harus tunai dan spesifik; (e) Modal syirkah harus memiliki nilai dan manfaat secara mutlak. ${ }^{42}$

Maka obligasi dengan kosep ini

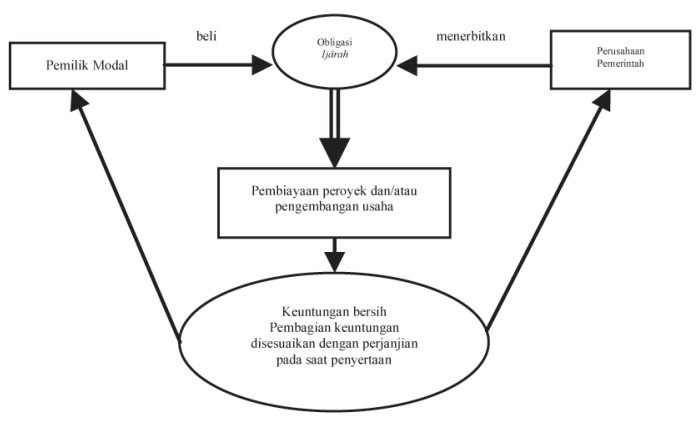

\section{Penentuah Harga Obligasi Musyârakah}

Obligasi musyârakah memberikan keuntungan dengan bentuk pemberian bagi hasil dari hasil usaha yang diberikan setiap triwulan, semester atau tahunan. Current yield pada obligasi musyârakah diartikan sebagai proporsi penghasilan obligasi yang berasal dari hasil usaha emiten/issuer relatif dengan harganya.

Current yield $=$ (nominal bagi hasil : harga obligasi musyârakah) $\times 100 \%$.

\footnotetext{
39 ،Abd Allâh ibn Ahmad Ibn Qudâmah, al-Mughnî, Jilid II, h. 211.

${ }^{40}$ Ibn 'Âbidîn, Hasiyah Mukhtâr 'ala Dâr al Mukhtar, (Bayrût: Dâr al-Fikr, t.th), jilid 3, h. 364.

${ }^{41}$ Wahbah al-Zuhaylî, al-Fiqh al-Islâmî wa Adillatuh, Juz V, h. 3879.

${ }^{42}$ Wahbah al-Zuhaylî, al-Fiqh al-Islâmî wa Adillatuh, Juz V, h. 3889-3895.
} 
Contoh: PT. Lintas Data Utama mengeluarkan obligasi musyaraka dengan harga rata-rata tertimbang (weight average price) Rp 8,5 juta. Berapakah hasil tahunan berjalannya (current yield) jika pembayaran bagi hasil dilakukan pertahun. Jawab: Hasil yang diberikan oleh PT Lintas Data Utama adalah Current yield = besarnya nilai bagi hasil : harga obligasi. Current yield $=(\mathrm{Rp} 1.800 .000: \mathrm{Rp}$ $8.500 .000) \times 100 \%=21,17 \%$

Disamping keuntungan yang diberikan sesuai kontrak (per triwulan, semester dan tahunan) pemilik obligasi musyârakah juga dapat memperoleh keuntungan sampai masa obligasi tersebut habis. Keuntungan berdasarkan yield to maturity merupakan perhitungan keuntungan yang penting. Investor akan menerima hasil sesuai yield to maturity yaitu sebanding dengan harga yang dibayar oleh investor apabila dua asumsi terpenuhi, yaitu: (1) investasi obligasi dilakukan sampai jatuh tempo; (2) semua pembayaran bagi hasil diinvestasikan kembali pada tingkat yield to maturity.

Ada dua metode menghitung yield to maturity, yaitu rumus harga obligasi dan rumus pendekatan. Rumus harga obligasi:

Harga obligasi $=\frac{\text { bagi hasil }+ \text { bagi hasil }+(\text { bagi hasil }+ \text { nominal })}{(1+\text { ytm })}$

Rumus pendekatan:

Ytm $=\{$ bagi hasil + (nilai nominal - harga obligasi $): n\}:$

$\{$ (nilai nominal +harga obligasi $\}: 2\} \times 100 \%$

$\mathrm{n}=$ periode jatuh tempo

Untuk menghitung penghasilan obligasi sampai penerbit melunasi semua pokok penyertaan adalah yield to maturity. Jika current yield hanya memperhitungkan penghasilan bagi hasil tahunan relatif terhadap harganya maka yield to maturity memperhitungkan pendapatan bagi hasil dan capital gain/loss. yield to maturity merupakan tingkat keuntungan yang dinikmati investor jika obligasi musyârakah dimiliki sejak dibeli hingga jatuh tempo. yield to maturity merupakan tingkat keuntungan bagi hasil yang diterima pemegang saham sehingga present value obligasi sesuai dengan harganya. Contoh: berapaah ytm obligasi PT Lintas Data Utama jika jatuh tempo 5 tahun? Jawab: Ytm $=\{$ bagi hasil + (nilai nominal - harga obligasi) $: \mathrm{n}\}:\{$ (nilai nominal + harga obligasi) $: 2\}$. Ytm $=\{\mathrm{Rp}$ $1.800 .000+(\operatorname{Rp} 10.000 .000-\operatorname{Rp} 8.500 .000): 5\}:\{(\operatorname{Rp~10.000.000~}+\operatorname{Rp} 8.500 .000)\}$ : 2$\} \times 100 \%$. Ytm $=7,135 \%$. 


\section{Penutup}

Obligasi konvensional didefinisikan sebagi sebuah instrumen di mana penerbit berjanji akan membayar kembali sejumlah pinjaman berikut bunga dalam jangka waktu tertentu. Penerbit dapat berupa perusahaan atau pemerintah. Bunga biasa dibayar dalam jarak waktu enam bulan atau empat bulan. Ketika jatuh tempo, investor menerima keseluruhan jumlah yang diinvestasikan (modal). Jika dicairkan sebelum jatuh tempo, akan dikenakan denda.

Obligasi konvensional—sebagaimana dikemukakan di atas—sejatinya dilarang oleh syariah karena obligasi bersifat utang, sedangkan menurut syariah, utang-piutang (qardh) adalah "memberikan sesuatu kepada orang lain dengan perjanjian akan membayar yang sama dengan itu." ${ }^{43}$ Utang-piutang (qardh) adalah bentuk kegiatan muamalah yang bercorak ta'âwun (tolong-menolong) kepada pihak lain tanpa bermaksud mengambil keuntungan sedikitpun dari orang yang diberi utang. Dengan arti kata ketika seseorang diberi utang tidak boleh ada kelebihan pengembalian yang diambil dari orang yang diutangi kecuali senilai dengan barang yang diutangi.

Obligasi syariah, dengan demikian, dapat digunakan sebagai salah satu sumber pembiayaan dan merupakan salah satu instrumen keuangan syariah yang akan berkembang pesat, obligasi syariah tersebut berbeda dengan obligasi konvensional, obligasi syariah merupakan penyertaan dana dengan akad antara lain: mudhârabah (muqâradah), musyârakah, murâbahah, salam, istisnâ', dan ijârah. []

\section{Pustaka Acuan}

\section{Al-Qur'ân al-Karîm}

'Abd al-Mun'in, Muhammad, al-Mudhârabah wa Tathbîqâtihâ al-'Amaliyyah fi alMashârif al-Islâmiyyah, al-Qâhirah: al-Ma'ahad al-'Aimi li al-Fikr al-Islâmî, 1996.

'Abd al-Rahmân al-Juzayrî, Kitâb al-Fiqh 'alâ al-Madzâhib al-Arba'ah, Bayrût: Dâr al-Kutub al-'Ilmiyyah, 1990.

'Abd al-Wâhid, Muhammad ibn, Syarh Fath al-Qâdir Ma'a al-Inâyah, Bayrût: Dâr al-Fikr, t.th.

'Imârah, Muhammad, Qâmûs al-Musthalahât al-Iqtishâdiyyah fi al-Hadârah alIslâmiyyah, Bayrût: Dâr al-Masyrûq, 1993.

Abu al-Barakât, Ahmad al-Dardirî, al-Syarh al-Kabîr ma'a Hasiyyah al-Dasuqi, Bayrût: Dâr al-Fikr, t.th.

\footnotetext{
${ }^{43}$ Al-Sayyid Sâbiq, Fiqh al-Sunnah, (Bayrût: Dâr al Fikr, 1992), Juz III, h. 182.
} 
Bânî, al-, Muhammad Nashûr al-Dîn, Dha'îf Sunan ibn Mâjah: li al-Imâm al-Hâfizh Abî 'Abd Allâh Muhammad ibn Yazîd al-Qazwaynî, Riyadh: Maktabah alMa'arif, 1997.

Cahyana, Cahyana, Berinvestasi di Obligasi, Jakarta: Gramedia, 2003.

Elton, Edwin J. and Martin J. Gruber, Modern Portfolio Theory and Investment Analisys, (New York: Jhon Wiley, 1987).

Fabozzi, Frank J., (dkk), Foundation of Financial Market and Institutions, Terj. Chaerul Djakman, Pasar dan Lembaga Keuangan, Jakarta: Salemba Empat, 1999.

Gusniarti, Obligasi Syariah Mudhârabah (Upaya Memahami Obligasi Syariah Mudhârabah dalam Hukum Islam), Tesis, Jakarta: UIN Jakarta, 2004.

Hâsyiyah ibn 'Âbidîn, Radd al-Mukhtâr, Bayrût: Dâr al-Fikr, t.th.

Ibn 'Abidîn, Radd al-Mukhtâr 'ala al-Durr al-Mukhtâr, Bayrût: Dâr al-Fikr, t.th.

Ibn Qudâmah, 'Abd Allâh Ibn Ahmad, Mughnî, Bayrût: Dâr al-Fikr, 1405 H.

Ibn Rusyd, Bidâyah al-Mujtahid wa Nihayah al Muqtashid, Bayrût: Dâr al-Fikr, t.th.

Ma'luf, Abû Luis, Al-Munjid fi al-Lughah wa 'A'lâm, Bayrût: Masyriq, 1986.

Mâwardi, al-, Kifayah al-Akhyâr, Semarang: Maktab al-'Alawiyyah, t.th.

Radcliffe, Robert C. Investment, Concept, Analisys, Strategy, Florida: AddisonWesley Educational Publisher Inc., 1997.

Sâbiq, al-Sayyid, Fiqh al-Sunnah, Bayrût: Dâr al-Fikr, 1992.

Siddiq, Nejatullah M., Partnership and Profit Sharing in Islamic Law, Terj. Fakhriyah Mumtihani, Kemitraan Usaha dan Bagi Hasil dalam Hukum Islam, Yogyakarta: Dana Bhakti Prima Yasa, 1996.

Syaybânî, al-, al-Khatîb, Mughnî al-Muhtâj, Bayrût: Dâr al-Fikr, 1994.

Wahbah al-Zuhaylî, al-Fiqh al-Islâmî wa Adillatuh, Bayrût: Dâr al-Fikr, 1989. 